\title{
Exogenic DNAs May Influence Plant Adaptation Reactions to Changed Environment
}

\author{
V.A. Katsan, A.I. Potopalsky \\ Institute of Molecular Biology and Genetics, National Academy of Sciences of Ukraine \\ 150, Zabolotny Str., Kyiv, 03143, Ukraine \\ e-mail: potopalsky@imbg.org.ua
}

\begin{abstract}
The original technology of obtaining the tobacco plants possessing the complex of selectively useful features (accelerated development, high productivity, and resistance to complex salinization) has been elaborated, and inheritance of the physiologic and biochemic peculiarities of such plants has been investigated. To get the important and selective changes of yellow-leaved tobacco Krupnolistny 20 (KR 20, Large-leaved 20) cultivar, the native and alkylated by thiophosphamide DNA of salt-tolerant nightshade (Solanum nigrum L.) and DNA of pCAMVNEO and pTi8628 plasmids have been used. Its useful advantage is the provision of a wider change range and larger output of changed viable plants. The changes obtained by DNA action on tobacco and other plants exploited in technology elaboration have been analysed, and possible mechanism of plant heredity change by exogenic DNAs has been proposed.
\end{abstract}

Keywords: plants from solanaceous family, exogenous DNA, alkylated by thiophosphamide DNA, chlorophylls, carotene, xanthophylls, violaxanthine, luteine, salt resistance

Introduction The problem of breeding plant cultivars, capable of not only surviving in changed environment, but also of having proper productivity level, is as actual as never before. The problem of salinization is of special importance as in the world scale the area of salinized soil amounts to 900 million hectares and is constantly growing due to the usage of intensive agrarian technologies, artificial watering, as well as the introduction of soils, which are already salinized due to natural conditions, into usage $[1,2]$. The salinization of agricultural fields is a problem of more than 100 countries of the world, including the states that were a part of the Soviet Union, where, according to the data of the previous century end, it was about $10 \%$ on average, while in the countries of Middle Asia it reached 50-80\% [3]. Another important problem is climate changes and

C)V.A. KATSAN, A.I. POTOPALSKY, 2006 environment pollution by xenobiotics, which have both toxic and mutagenic influence on plants.

To obtain new forms of plants with a complex of selectively useful features, it is still more important to search the ways of variability expanding and these features transfer from wild plants.

The resistance to unfavourable conditions of environment, as well as quantitative features, determining the productivity and crop structure of plants, are polygenic. The genes, controlling the mentioned features, are disposed in different linkage groups, , therefore, there are difficulties in their transfer by the methods of gene engineering. For the first time the mutagenic action of exogenous DNAs was shown 67 years ago in the studies of Tarnavsky $[4,5]$ and Gershenson [6]. Gershenson et al. established the general features of action of natural and synthetic 
polynucleotides on living organisms $[7,8]$, and in the $70-80$ s of the previous century the possibility of obtaining selectively useful features of plants using DNA preparations was proved [9-12]. The mechanisms of exogenous DNAs (e-DNA) influence on heredity is a subject for discussions even nowadays, therefore, the investigation in this direction is not intensive enough.

As a result of investigations, which were conducted for more than thirty years, the methodology of changing plant heredity information using e-DNA preparations was elaborated in our laboratory, the important features of it are DNA selection as a donor of desired features or a mutagene (depending on taxonomic affinity of both the donor and the recipient), obtaining DNA preparations of the donor and their alkylation using tri-functioning alkylating agent thiophosphamide DNA (e-DNT), and the influence of mentioned preparations on germinating seeds of the recipient. The usage of these approaches allowed obtaining more than 40 new forms and cultivars of plants with desired features, among which there are the ones, which passed the State approbation of cultivars, are registered in Ukraine and recommended for practical application [9]. DNA concentration, the stage of seed germination, and the conditions of its infiltration with DNA solutions were selected individually for each plant cultivar in the experimental way.

The goal of this work is to elaborate the technology of obtaining new forms of tobacco plants with the complex of selectively useful features, among which are salt resistance, early maturation, high productivity, which could be used for breeding of modern cultivars, as well as to analyze e-DNA induced changes in plants.

Materials and Methods The tobacco cultivar, selected as a donor. The investigation was performed on the pure line of tobacco Krupnolistny 20 (KR 20) cultivar (the author O.P. Grebyonkin, NPO Tabak, Russia), the seeds of which were kindly given to us by B.O. Levenko (Gryshko National Botanical Gardens, NAS of Ukraine). KR 20 cultivar is distinguished by early apoptosis of industrial layer leaves. The plants acquire characteristic phenotype with light yellow colouring of middle layers leaves and green colouring of only plant tops on the primary stages of floral shoot growing. This phenotype is conditioned by the dominant mutation White, obtained by Kosmodemyansky using the method of chemical mutagenesis in 1965 [13]. Mutants, similar in phenotype, occur spontaneously as well, they are known for practically all agroecological tobacco groups and can be a consequence of mutations of both dominant and recessive genes [14]. The selectionists' attention was attracted to yellow-leaved mutations due to the fact that one of important indicators of raw material quality in tobacco production is the colour of leaves after their breaking off, withering, and drying the leaves, getting even golden-brown colouring are considered of high quality, and it is yellow-leaved tobacco cultivars that give the best output of highly qualitative raw material by colour feature [15]. However, all the mutations, known nowadays, which condition early apoptosis of industrial layer leaves of tobacco, are undoubtedly harmful, as they decrease plant viability and the content of economically useful substances in leaves which results in general quality loss of raw material.

The basis of the study on interconnection of biochemical indicators with the raw material quality for tobacco production was laid by A.A. Shmuk: first of all, besides absence of chlorophylls, the raw material of high quality is characterized by high content of carbohydrates, and optimal correlation among carbohydrates and proteins (Shmuk's number) [16]. The correlation of chlorophylls content to biochemical features of raw material quality in Krupnolistny tobacco cultivars was studied before [17].

The plants, used in a model system. New approaches were used while elaborating the technology of changing tobacco heredity features, therefore, the action of exogenous DNA was studied on the model system using KR 20 tobacco as well as wild plants from solanaceous family namely, stramonium Datura stramonium $L$., and cultivated plants of other families sorghum Horizont cultivar, millet Chervona Vatra cultivar, corn Delikatesna cultivar, poppy somniferous Novynka cultivar. Pure lines of these plants were obtained in our laboratory..

The plant - donor of selectively useful features. Salt-tolerant form of nightshade - Solanum nigrum $L$. was used as a donor. Salt-tolerant form of nightshade is a line of the plant, taken from natural population, and 
adapted to growing in the conditions of complex salinization (Rybakivka village, Ochakivsky district, Mykolayivsky region).

Obtaining DNA preparations. DNA extraction of nightshade and alkylation of obtained preparations by thiophosphamide were performed according to the methods, elaborated in our laboratory $[18,19]$. Purified DNA $p C A M V N E O$, containing the resistance gene to kanamycin from the bacterial transposon Tn5, was kindly given to us by O.P. Smirnov (Vavilov Institute of General Genetics, ,Russian Academy of Sciences, Moscow). DNA pTi8628 was extracted from Agrobacterium tumefaciens strain, infecting the cultures of plants [20].

The methods of statistical mathematics. To process the obtained results of the study we used the methods of estimating the average probability and the probability of differences between the experiment variants and the control by Student's criterion, selection of samples with a large variation range in classes as well as one factor scheme of variance analysis [21, 22].

Results and Discussion The optimal concentration of DNA preparations in the solutions for tobacco seeds infiltration was chosen in the experimental way, considering the data, obtained in our laboratory on tomatoes and other plants before, it amounted to $500 \mu \mathrm{g} / \mathrm{ml}$. DNA was introduced into the germinating seeds by the infiltration method. New approaches, used by us for technology elaboration, are as follows:

-to extend variability range of investigated features, the DNAs of the donor plant were used in the complex with the DNA of plasmids, which are the source of known mobile genetic elements ( $P C A M V N E O$, pTi8628);

-the duration of DNA preparations action was changed;

-the conditions of performing the germinating seeds infiltration by DNA solutions were changed.

The results of the study showed expressed genotype specificity of the influence of the DNA, used by us, on the selected plants, especially concerning genotoxic action, output of viable fertile plants and the ones, which had desired features as early as in the first generation (Table). The DNA of plasmids manifested the highest toxicity on the model system plants. The DNA of the nightshade in the chosen concentration was genotoxic for tobacco, therefore, its concentration in the complex preparation was decreased 3 -fold. The differences between the action of the alkylated and native DNA of nightshade also depended on the recipient genotype. The alkylation of nightshade DNA with thiophosphamide allowed not only removing its genotoxic effect on millet and tobacco at its usage in a high concentration $(500 \mu \mathrm{g} / \mathrm{ml})$, but also obtaining viable fertile plants, while alkylated DNA of nightshade turned out genotoxic for poppy. DNA pTi8628 was genotoxic for both tobacco and sorghum; DNA pTi8628 alkylation allowed obtaining fertile tobacco plants, but the germination of nightshade seeds decreased. The alkylation with thiophosphamide DNA $p C A M V N E O$ did not allow removing its genotoxic influence on all plants cultivars, studied by us, except tobacco: using e-DNT $p C A M V N E O$ we managed to obtain one tobacco plant (\#73) which turned out to be fertile. In general, using the approaches, elaborated by us, fertile plants were obtained for all the investigated cultivars, except corn. In the majority of experiment variants the desired changes in the presence of viable plants were observed on the tobacco cultivar KR 20 .

The technology, elaborated by us, allowed obtaining tobacco plants with changed phenotype concerning leaves colouring as well as with the preservation of chlorophylls in the leaves of industrial layers before the development completion, which also were distinguished by fast development and early terms of blooming comparatively to the control, they had large leaves and these features were inherited [25-27].

Salt resistance heredity was shown for plants from the variants where DNA or DNT of salt tolerant form of nightshade were used $(6.3 \pm 0.14-7.7 \pm 0.11$ and $9.8 \pm$ $0.10-10.4 \pm 0.12 \%$ of viable sprouts respectively, obtained in the medium with $20 \mathrm{~g} / 1$ sea salt from the plant seeds of the first generation). Likewise tomatoes $[3,9]$, selectively useful changes occurred as early as the first generation.

Obtaining of salt tolerant tobacco forms [25, 26] may prove genetic transformation of tobacco using the DNA of salt tolerant nightshade. Global changes in metabolism are known to take place in plants at salt stress which is caused by expression changes of about 1500 genes [27]. The nature of salt resistance in plants is controlled by a great number of genes and may be 
The influence of e-DNA and e-DNT preparations on the germination and appearance of the most characteristic phenotype changes in $T_{1}$ plants

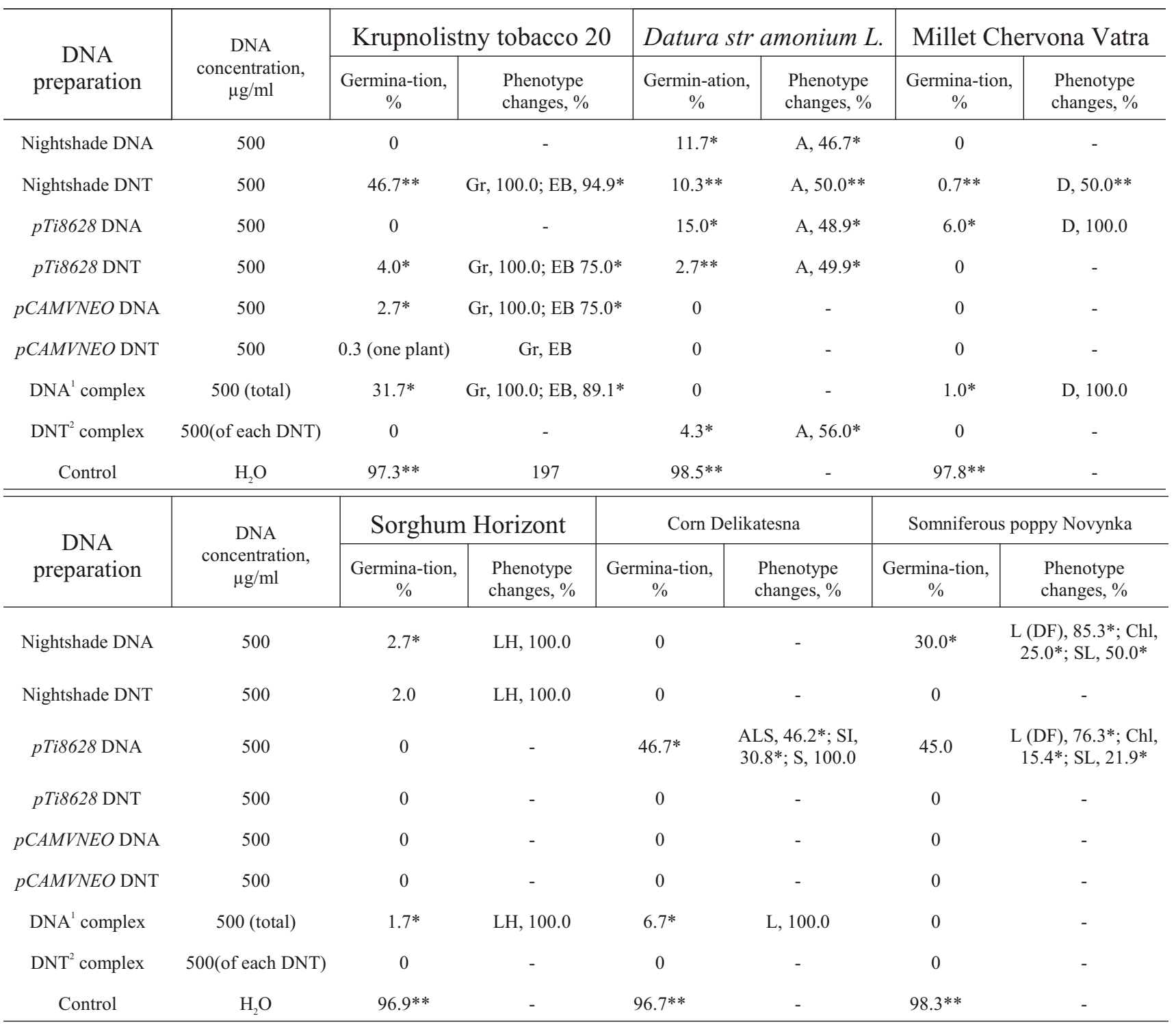

Note. ${ }^{1}$ DNA complex of nightshade and $p C A M V N E O$ and $p$ Ti 8628 plasmids, each DNA concentration is the third of $500 \mu \mathrm{g} / \mathrm{ml} ;{ }^{2} \mathrm{DNT}$ complex of the same origin, each DNT concentration $-500 \mu \mathrm{g} / \mathrm{ml}$. The variability degree of the given maximum values of the investigated parameters: ${ }^{*} \mathrm{p}>0.95 ; * * \mathrm{p}>0.99$ at $\mathrm{n}=5$. Phenotypes deciphering: A - anthocyane colouring of flowers and plants (stramonium): L - lethality on early stages of development; DF - dwarfish plants with anthocyane colouring (poppy); Chl - light (light green) colour of leaves; SL - small leaves; D- dwarfish plants; LH - low height plants; Gr "green" development type (chlorophylls preservation in the leaves of industrial layers to the development completion, tobacco); EB - early blossoming phenotype (tobacco); ALS - anthocyane colouring of leaves and stems (corn); SI - "spike-like male inflorescence" (corn); S - sterility (connected with heterochronous development anthers and ears of corn).

conditioned by phenomena which are provided by the mechanisms of control of ions transport and antiport through the plasmatic membrane, the transport of ions surplus from the cytoplasm into vacuoles and by the biosynthesis of substances that have protection features at abiotic stresses (proline, betaines, trehalose, myoinositol, polyamines, etc) as well as by the activation of systems, neutralizing reactive oxygen forms at the participation of glutathione and by the expression increase of nucleic acids processing genes, DNA-helicase and biosynthesis of PR-proteins, in particular [28-36]. Salt resistance in plants is practically 
a quantitative feature as it can be increased due to the reinforcement of one of these metabolism pathways by employing genetic construction containing 1-2 genes [28-35]. Several mechanisms can participate in the acquisition of salt resistance by plants, therefore, using e-DNA, it is much simpler and more reliable to obtain salt tolerant plants which was proved by our investigations on tobacco and by obtaining a salt tolerant tomato cultivar [3, 9].

The characteristic feature of the influence of e-DNAs, used according to the elaborated technology, is the induction of a large amount of changes in the first generation plants. Practically all the obtained tobacco plants turned out to be changed - in height, development terms, form and colouring of leaves. The most characteristic feature was the recovery of the wild green phenotype by plants. The inheritance of this feature was shown in the lines of plants, selected from different variants [23-26]. Also we revealed e-DNA capability of inducing both quantitative and qualitative hereditary changes in the accumulation of photosynthetic pigments, which were analysed by us in detail [23, 24].

Among modifications, obtained from plants using e-DNA, there are some which may serve as a proof of e-DNA influence on genetic systems, responsible for the adaptation to changed environment. First of all, this is the inheritance of salt resistance and some changes in photosynthetic pigments accumulation, the changes in chlorophylls $a$ and $b$ ratio, obtained from tobacco using DNA of nightshade, in particular [24-26]. The reaction of chlorophyll $a$ conversion into chlorophyll $b$ is known to be catalysed by chlorophyllid $a$ oxygenase, it regulates the size of the main light-harvesting complex (LHC II) and is underlying the plants adaptation to the changes of lightening conditions [37]. The increase of violaxanthine cycle pigments amount [24-26] can also be important for adaptation, as the compounds, which are generated by violaxanthine cycle, regulate safe dissipation of the excess of absorbed energy [38].

Besides, violaxanthine is a substrate for the biosynthesis of the abscisic acid, which is very important for the stress responses in plants [39]. In its turn, the general increase of xanthophylls and carotene content [24] may be important for adaptation processes, considering a significant biological function of these pigments as scavengers of free radicals, that are formed out of oxygen and chlorophylls and may become a reason of damaging photosynthetic membranes. The increased portion of chlorophyll $a$, which is a part of the reaction centres, and lutein $[24,26]$ which is a component of pigment complexes, surrounding the reaction centre, may indicate the increase of photosystems amount. The increased amount of chlorophylls in tobacco testifies to the resistance to diseases: tobacco mosaic, peronosporosis, and phytophthorosis [40]. Quantitative and qualitative changes in the photosynthetic apparatus are likely to be directed towards generating compositions and energy, necessary for plant adaptation to changed environment, as photosynthesis is the most sensitive function of plants, which reacts to stressors first and foremost, therefore the composition and qualitative correlations of photosynthesis products change considerably depending on the organism condition [41].

Both the appearance of anthocyanin pigments in the plant top and the change of flowers colouring from usual white to violet colour may have protective meaning, which was revealed in the investigation of stramonium (D. stramonium), and this feature was also inherited. The change of stramonium crown colouring also reminds phenomena, conditioned by the transposon transfer [42].

Another group of features, caused by e-DNA in $T_{1}$ tobacco plants, is non specific reactions of resistance to kanamycin and to spontaneous infecting by viruses, which are present in the environment [43]. It may testify to the induction of changes in metabolism, connected with the adaptation to some stress agents.

The proof of e-DNA influence on regulatory systems, responsible for the adaptation to changed environment, may be in morphological changes, obtained in $T_{1}$ plants under the influence of e-DNA: reduced stems of Chervona Vatra millet (like mountain plants), smaller leaves and narrowed leaf plate in tobacco and poppy (a xenomorphic feature), the decrease of height and the appearance of brachytic forms among the plants of all the investigated cultivars (Table).

Hereditary changes in chlorophylls accumulation, revealed in tobacco, as well as hereditary changes of plants habitus (height decrease, inhibition of apical 
domination with the formation of a significant amount of side shoots) resemble the complex of hereditary changes, obtained in tobacco mutants with the increased expression of phytochrome A gene, modulating the level of gibberellins in the vascular tissues [44]. Tobacco mutants with decreased expression of phytochrome B gene are characterised by a complex of other changes - apical domination and chlorophylls content like mutants of chlorine [45]. Functioning chloroplasts are necessary for the establishment of system acquired resistance in plants. The interaction of signal transduction pathways, induced by light, with signal pathways, initiated by phytopathogens and mediated by salicylic acid, takes place in this case [46, 47], while the resistance to pathogens may be caused by changing phytochrome genes expression [46].

The analysis of our investigation results as well as literature data concerning the molecular nature of phenomena and processes, which are influenced by e-DNA, may become the foundation of the hypothesis concerning one of important ways of e-DNA influence on plants - it is implemented at the action on sprouting seeds and it causes the changes of expression and genes mutations, responsible for the recognition of signals about changed environment and the direction of responses to these changes. The key genes of signal systems are surely the most open and available ones, hence they change in the first place; they are also cross points of signal ways interacting, initiated by phytochromes, nutrients and agents of abiotic and biotic stresses [48-50], which conditions pleiotropic effect of these mutations.

Instability of the chlorophylls content in tobacco (the appearance of plants phenotypes in $T_{1}$ which were 1.4-3.7 times different in chlorophylls content, and splitting of selected plants in $\mathrm{T}_{2}$ generation into forms that were two times and more different in chlorophylls content $[23,24]$ as well as the appearance of flowers with white and mosaic colouring in $\mathrm{T}_{1}$ (Figure)) may evidence to e-DNA influence on systems, regulating transposon transfer. The phenomenon of form-building process activation in plants with the participation of mobile genetic elements under the influence of changed environment was discovered by McClintock [51]. The universality of the transposon transfer activation of drosophila at the influence of different stress agents (heat-shock, chemical mutagenes, and e-DNA of viral origin) was shown by Georgiev [52].

A considerable contribution into the study of systems functioning of genome regulation using mobile genetic elements was made by Ratner (the study of block-module principle of genome organization and mobile systems of genetic information regulation) [53-55]. The study of Moscow scientists is devoted to the significance of mobile genetic elements in the adaptive changes occurrence $[56,57]$. The similarity of genes changes, caused by e-DNA in drosophila, with the effects, conditioned by the "controlling elements action" (exceptional locus-specificity, prolonged action, and instability in generations) was remarked by Gershenson who supposed that e-DNA fragments can act as transposons, destabilising the recipient genes [58, 59], later Alexandrov and Gershenson suggested a hypothesis concerning the e-DNA influence mechanism due to the activation of transposons transfer in the recipient [60]. The participation of transposons in the expression of hereditary changes in drosophila due to e-DNA action was also proven by experiments [8].

In our opinion, the spectrum of changes, induced in drosophila by e-DNA, is worth considering as these are mainly mutations connected with the change of sizes, forms, and nervation [59], which can have adaptive significance for insects. Adaptive changes in plants were revealed in our investigations as well as by many other scientists [9-12]. Thus, one of the action mechanisms of exogenous DNA on hereditary features of the recipient, which is very important for selectionists, can be the activation of regulation systems, which are responsible for the adaptation to changed environment that may find its implementation not only in the expression changes of the most important genes but also in their hereditary modifications.

At the e-DNA influence on plants, used in our experiments, we observed the appearance of features, which are characteristic of plants of related taxons that may be the demonstration of parallel variability according to Vavilov [61]. These changes may include the appearance of violet flowers of usual stramonium (the hereditary features, which are similar to that of Indian stramonium), the spike-like form of male 

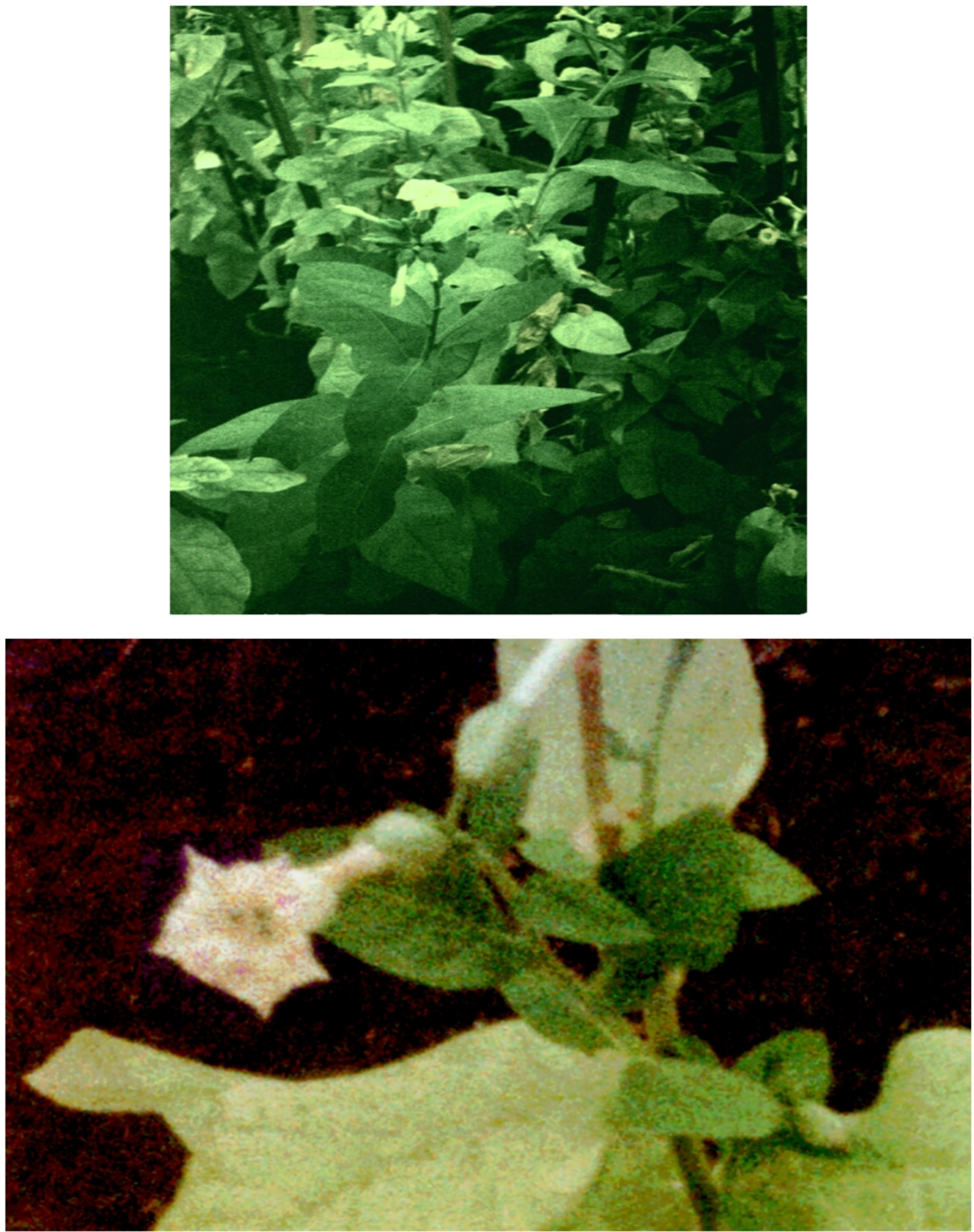

Plants with changed colouring of leaves in $\mathrm{T}_{1}$ generation: $a$ - white flowers of plant $\# 60$ of the $1^{\text {st }}$ generation in experiment $\# 1$ variant, where we used DNA complex of nightshade and $p$ Ti8628 and $p C A M V N E O ; b$ - mosaic petal colouring of plant \#73 from experiment \#3 variant (DNT $p C A M V N E O$ ) 
inflorescence of corn, the formation of a number of side shoots of tobacco, the decrease of cycle duration of its development and the change of flowers colour from pink to white (the features of nightshade). In our opinion, it is Vavilov's law that is one of the most important manifestations of formative processes in plants, conditioned by fundamental features of the systems of preservation and regulation of genetic information, which were specified by Ratner [53-55].

\section{Conclusions}

1. The original technology of obtaining tobacco plants with desired hereditary features namely, resistance to complex salinization, early maturation, increased productivity, using e-DNA was elaborated. The result of its usage was the obtaining of tobacco lines which may become the basis for the breeding of modern highly productive cultivars, resistant to complex salinization.

2. On the basis of the analysis of changes, obtained in tobacco using e-DNA, as well as changes which were observed at the influence of e-DNA on plants and drosophila by other researchers, the theoretical mechanism of e-DNA influence on plant heredity was suggested. It can be used in both biotechnology and selection.

\section{В. А. Каиан, А. И. Потопальский}

Экзогенные ДНК могут влиять на регуляторные системы растений, отвечающие за адаптацию к изменениям в окружающей среде

Резюме

Разработана оригинальная технология получения растений табака, обладающих комплексом селекиионно ценных признаков (ускоренное развитие, повышенная продуктивность, устойчивость к комплексному засолению почвы) при помощчи препаратов экзогенных ДНК (э-ДНК), изучены физиолого-биохимические особенности таких растений и их наследование. Для индуцирования желаемых изменений у желтолистного сорта табака Крупнолистный 20 использована ДНК солеустойчивой формы паслена черного Solanum nigrum L., а также ДНК плазмид рСАMVNEO и рTі8628. Важное преимущество разработанной технологии? обеспечение более широкого спектра изменений и более значительный выход измененных жизнеспособных растений. На основе анализа модификачий, обнаруженных у табака и растений модельной системы, использованных при разработке технологии, предложен гипотетический механизм влияния э-ДНК на наследтвенные признаки растений.

Ключевые слова: пасленовые, экзогенные ДНК, алкилированная тиофосфамидом ДНК, хлорофилль, каротины, ксантофилль, виолаксантин, лютеин, солеустойчивость.
REFERENCES:

1. Flowers T. G. Improving crop salt tolerance // J. Exp. Bot.-2004.-55.-P. 307-319.

2. Schoups G., Hopmans J. W., Young C. A., Vrugt J. A., Wallender W. $W$., Tanji K. K. Sustainability of irridated agriculture in the San Joaquin Valley, California // Proc. Nat. Acad. Sci. USA.-2005.-102.-P. 15352-15356.

3. Потопальский А. И., Качан В. А., Юркевич Л. Н., Ковалев В. А. Томаты сорта Украинский солеустойчивый и перспективные линии, полученные на их основе // Овощеводство и бахчеводство.-2005.-51.-С. 168-180.

4. Тарнавский Н. Д. К вопросу о роли нуклеиновой кислоты при конъюгации хромосом // Докл. АН СССР._1938.—20, № 9.-С. $721-724$.

5. Тарнавський М. Д. До питання про роль нуклеїнової кислоти при викликанні направлених мутацій // Доп. АН УРСР.-1939.—№ 1.-C. 47-49.

6. Гершензон С. М. Вызывание направленных мутаций у Drosophila melanogaster // Докл. АН СССР.-1939.-25, № 3.-С. 224-227.

7. Гершензон С. М., Александров Ю. М., Малюта С. С. Мутагенное действие ДНК и вирусов у дрозофилы.-Киев: Наук. думка, 1975.-159 с

8. Гершензон С. М. Избирательность мутагенного действия ДНК и других полинуклеотидов // Журн. общ. биологии.-1996.-57, № 6.-P. 661-682.

9. Каиан В. А., Потопальський А. І., Юркевич Л. Н. Отримання рослин з господарсько цінними ознаками за допомогою екзогенних ДНК // Матеріали міжнар. форуму «Основи молекулярно-генетичного оздоровлення людини і довкілля» (Київ, 31 травня-1 червня 2005 р.).-Київ, 2005.-С. 84-87.

10. Сиволап Ю. М., Образиов С. И. Возможность генетической трансформации у высших растений // Республ. межвед. сб. «Молекулярная биология» (Киев).-1980.-Вып. 26.-С. 3-8.

11. Картель Н. А. Эффекты экзогенной ДНК у высших растений.-Минск: Наука и техника, 1981. -143 с.

12. Ларченко E. А., Моргун В. В. Экспериментальная изменчивость кукурузы.-Киев: Наук. думка, 1993.-173 с.

13. Космодемьянский В. Н., Рубан Э. В., Иванова Т. 3. Доминантная мутация White, индуцированная N-нитрозомочевиной у табака // Практика химического мутагенеза.-М.: Наука, 1971.-С. $179-183$

14. Бучинский А. Ф. Особенности желтолистных форм Nicotiana tabacum L. // Сб. работ по селекции, генетике и семеноведению табака и махорки (ВНИИТиМ).-Краснодар, 1936.-Вып. 132.-C. $37-54$

15. Иванова T. 3. Популятивность сортов табака по цвету и качеству // Табак.-1967.-№ 4.-С. 53-54.

16. Шмук А. А. Химия и технология табака.-М.: Пищепромиздат, 1953.-T. 3.-776 c

17. Баранова Е. Г. Генетические особенности наследования признаков химического состава сортов табака и использование их в селекции: Автореф. дис. ... канд. биол. наук / НИИ земледелия АН Армении.-Эчмиадзин, 1990.-25c.

18. А. с. СССР № 1170871 Т, МКИ С 12 N 15/00, С 07 Н 21/00. Способ получения дезоксирибонуклеиновой кислоты из растительного сырья / 3. Ю. Ткачук, А. И. Потопальский // Выдано 01.04.85.

19. Волощук Т. П., Паиковский Ю. В., Потопальский А. И. Алкилирование компонентов нуклеиновых кислот этиленимином и его производными. 4. Алкилирование гомонуклеотидов и ДНК // Биоорг. химия.-1999.-25, № 6.-С.464 473 .

20. Маниатис T., Фрич Э., Сэмбрук Дж. Молекулярное клонирование.-М.: Мир, 1984.-479 с

21. Кокунин В. А. Статистическая обработка данных при малом числе опытов // Укр. биохим. журн.—1975.—47, № 6. - С. 776-790

22. Плохинский Н. А. Биометрия.-М.: Изд-во МГУ, 1970.-367 с. 
23. Потопальский А. И., Каиан В. А., Леськив М. Е. Влияние экзогенных нативных и модифицированных нуклеиновых кислот на биосинтез фотосинтетических пигментов у Nicotiana tabacum L. 1. Содержание хлорофиллов и каротиноидов у растений первого поколения // Биополимеры и клетка.-1995.-11, № 2.-C. $88-99$.

24. Кацан В. А., Потопальский А. И. Влияние экзогенных нативных и одифицированных нуклеиновых кислот на биосинтез фотосинтетических пигментов у Nicotiana tabacum L. 2. Динамика содержания хлорофиллов и каротиноидов у растений второго и третьего поколений // Биополимеры и клетка.-2000.-16, № 1.-C. $22-34$.

25. Кацан В. А., Потопальский А. И., Юркевич Л. Н. Використання екзогенних ДНК для корекції програми розвитку жовтолистого мутанту Nicotiana tabacum L. // Фактори експериментальної еволюції організмів.-Київ: Аграрна наука, 2003.-С. 339-345.

26. Потопальский А. И., Кацан В. А., Юркевич Л. Н. Итоги и перспективы получения растений семейства пасленовых с помощью нативных и модифицированных ДНК // Овощеводство и бахчеводство.-2005.-51.-C. 181-197.

27. Ma S., Gong Q., Bohnert H. J. Dissecting salt stress pathways // J. Exp. Bot.-2006.-57.-P. 1097-1107.

28. Wu C. A., Yang G. D., Meng Q. W., Zheng C. C. The cotton GhNHXI gene encoding a novel putative tonoplast $\mathrm{Na}^{+} / \mathrm{H}^{+}$antiporter plays an important role in salt stress // Plant Cell Physiol._2004._45.-P. $600-607$.

29. Kishor K., Hong Z., Miao G.-H., Hu C.-A. A., Verma D. P. S Overexpression of pyrroline-5-carboxylate synthetese increases proline production and confers osmotolerance in transgenic plants // Plant Physiol.-1995.-108.-P. 1387-1394.

30. Holmstrom K.-O., Somersalo S., Mandal A., Palva T. E., Welin B. Improved tolerance to salinity and low temperature in transgenic tobacco producing glycine betaine // J. Exp. Bot.-2000.-51.-P. $177-185$

31. Jang I. C., Oh S. J., Seo J. S., Choi W. B., Song S. I., Kim C. H., Kim Y. S., Seo H. S., Choi Y. D., Nahm B. H., Kim J. K. Expression of a bifunctional fusion of a Escherichia coli genes for tregalose-6-phosphate synthase and tregalose-6-phosphate phosphatase in transgenic rice plants increases tregalose accumulation and abiotic stress tolerance without stunting growth // Plant Physiol.-2003.-131.-P. 516-524.

32. Das-Chatterjee A., Goswami L., Maitra S., Dastidar K. G., Ray S., Majumder A. L. Introgression as a novel salt-tolerant L-myo-inositol 1-phosphate synthase from Posterresia coarctata (Roxb.) Tateoka (PcINO1) confers salt tolerance to evolutionary diverse organisms // FEBS Lett.-2006.-580.-P. 3980-3988.

33. Wi S. G., Kim W. T., Park K. Y. Overexpression of carnation S-adenosinmethionine decarboxylase gene generates a broad-spectrum tolerance to abiotic stresses in transgenic tobacco plants // Plant Cell Rep._-2006._-Epub. ahead of print.

34. Singla-Pareek S. L., Reddy M. K., Sopory S. K. Genetic engineering of the glyoxalase pathway in tobacco leads to enhanced salinity tolerance // Proc. Nat. Acad. Sci. USA.-2003.-100.-P. $14672-14677$.

35. Sanan-Mishra N., Pham X. H., Sopory S. K., Tuteja N. Pea DNA helicase 45 overexpression in tobacco confers high salinity tolerance without affecting yield // Proc. Nat. Acad. Sci. USA.-2005.-102.-P. 509-514.

36. Yen H. E., Edwards G. E., Grimes H. D. Characterization of a salt-responsive 24-kilodalton glycoprotein in Mesembryanthemum crystallinum // Plant Physiol._-1994._105._P. 1179_-1187.

37. Yamasato A., Nagata N., Tanaka R., Tanaka A. The N-terminal domain of chlorophyllide a oxygenase confers protein instability in response to chlorophyll b accumulation in Arabidopsis // Plant Cell.-2005.-17.-P. 1585-1597.

38. Pogson B., McDonald K., Tround M., Britton G., DellaPenna D. Arabidopsis carotenoid mutants demonstrate that lutein is not essential for photosynthesis in higher plants // Plant Cell.-1996.-8.-P. 1627-1639.

39. Gonzalez-Guzman M., Abia D., Salinas J., Serrano L., Rodriguez P. $L$. Two alleles of the abscisic oxygenase 3 gene reveals its role in abscisic acid biosynthesis in seeds // Plant Physiol.-2004.-135.-P. 325-333.

40. Espino E., Xiomara R., Garsia V., Garsia Y. H., Habana P. R. Nueva variaded de tabaco negro (Nicotiana tabacum) con resistancia multiple y buenas caracteristicas comerciales // Agrotech. Cuba.-1989.-2.-P. 9-13.

41. Энергетические аспекты устойчивости растений / Под ред. И. А Тарчевского.-Казань: Изд-во Казан. ун-та, 1986.-140 с.

42. Хесин Р. В. Непостоянство генома.-М.: Наука, 1984.-472 с.

43. Кацан В. А., Потопальский А. И., Леськив М. Е. Устойчивость к канамицину растений табака при воздействии препаратов ДНК на семена // Биополимеры и клетка.-1996.-12, № 2.-С. $47-55$.

44. Jordan E. T., Hatfield P. M., Hondrid D., Talon M., Zeevart A. D., Viestra R. D. Phytochrome A overexpression in transgenic tobacco // Plant Physiol.-1995._107.—P. 797-805.

45. Peng J., Harberd N. P. Gibberellin deficiency and response mutations suppress the stem elongation phenotype and phytochrome-deficient mutants of Arabidopsis // Plant Physiol.-1997.-113.-P. $1051-1058$.

46. Genoud T., Buchala A. J., Chua N. H., Metaux J. P. Phytochrome signalling modulates the SA-perceptive pathway in Arabidopsis // Plant J.-2002.-31.-P. 87-95.

47. Zeiter J., Pink B., Mueller B. J., Berger S. Light conditions influence specific defence responses in incopatible plant-pathogen interactions: uncoupling systemic resistance from salicylic acid and PR-1 accumulation // Planta.-2004.-219.-P. 673-683.

48. Buchanan-Wollaston V., Page T., Harrison E., Breeze E., Lim P. O., Nam H. G., Lin J.-F., Wu S.-H., Swidzinski J., Ishizaki K., Leaver C. Comparative transcriptome analysis reveals significant differences in gene expression and signalling pathways between developmental and dark/starvation induced senescence in Arabidopsis // Plant J.-2005.-42.-P. 567-585.

49. Gibson S. I. Sugar and phytochrome response pathways: navigating a signalling network // J. Exp. Bot.-2004.-55.-P. 253-264.

50. Monte E., Alonso J. M., Ecker J. R., Zhang Y., Li X., Young J., Austin-Philips S., Quail P. H. Isolation and characterization of phyC mutants in Arabidopsis reveals complex crosstalk between phytochrome signalling pathways // Plant Cell._-2003._-15.-P. $1962-1980$.

51. McClintock $B$. The significance of responses of the genome to challenge // Science.-1984.-226.-P. 792-801.

52. Георгиев П. Г. Роль мобильных генетических элементов в мутагенезе, индуцированном химическими и физическими агентами: Автореф. дис. ... канд. биол. наук / Институт молекулярной биологии им. Н. Г. Энгельгардта.-Москва, 1991.-23 с.

53. Ратнер B. A. Блочно-модульный принцип организации и эволюции молекулярно-генетических систем управления (МГСУ) // Генетика.-1992.-28, № 2.-C. 5-24.

54. Ратнер В. А., Васильева Л. А. Роль мобильных генетических элементов в микроэволюции // Генетика.-1992.-28, № 12.-C. $5-17$.

55. Ратнер В. А., Васильева Л. А. Критические ограничения геномной системы мобильных генетических элементов (МГЭ) // Генетика.-1994.-30, № 5.-С. 593-599.

56. Гвоздев В. А., Кайданов Л. З. Системные изменения локализации мобильных элементов в геноме Drosophila melanogaster, сопровождающие процессы селекции // Молекулярные механизмы генетических процессов.-М.: Наука, 1990.-С. 26-36.

57. Беляева Е. С., Пасюкова Е. Г., Гвоздев В. А. “Адаптивные транспозиции" ретротранспозонов в геноме Drosophila melanogaster, сопровождающиеся увеличением приспособленности особей // Генетика.-1994.-30, № 6.-С. 725-730. 
58. Гершензон С. М. Мутагенное действие ДНК и проблема направленных мутаций // Генетика.—1966.-№ 5.-С. 3-15.

59. Гершензон С. М. Мутагенное действие ДНК, инсерции, транспозиции и нестабильные гены // Генетика и благосостояние человечества: Tp. XV Междунар. генет. конгр.-М.: Наука, 1981.-C. 304-318.

60. Гершензон С. М., Александров Ю. М. Мутагенное действие природных и синтетических полинуклеотидов и проблемы направ- ленных мутаций // Журн. общ. биологии.—1982.—43, № 6.-С. $747-763$

61. Вавилов Н. И. Закон гомологических рядов в наследственной изменчивости.-Ленинград: Наука, 1987.-260 с.

УДК 575.224:577.113
Надійшла до редакці1 19.06 .06 